Journal of Sustainable Development of Transport and Logistics

journal home page: https://jsdtl.sciview.net

Mogaka, C. O., \& Arani, W. (2020). Logistics strategy as a competitive tool for firm performance: The moderating effect of customer service effectiveness. Journal of Sustainable Development of Transport and Logistics, 5(1), 56-65. doi:10.14254/jsdtl.2020.51.6.

\title{
Logistics strategy as a competitive tool for firm performance: The moderating effect of customer service effectiveness
}

\author{
Conrad Ochego Mogaka *, Wycliffe Arani ** \\ * Department of Procurement and Logistics, School of Entrepreneurship, Procumbent and Management, \\ Jomo Kenyatta University of Agriculture and Technology, \\ P.O. Box 62000 - 00200 Nairobi, Kenya \\ mogakaconrad@gmail.com \\ ${ }^{* *}$ Faculty of Business and Economics, Multimedia University of Kenya, \\ P.O BOX 15653-00503 Nairobi, Kenya \\ araninemuel@gmail.com
}

open access CC do

Article history:

Received: January 15, 2020

1st Revision: February 22,

2020

Accepted: April 08, 2020

DOI:

10.14254/jsdtl.2020.5-1.6
Abstract: The goal of this research paper is to explore logistics strategy as a competitive tool for firm performance; the moderating effect of effectiveness of customer service: by presenting academic and practical advantages by explaining the preceding and suggesting a forward-looking research agenda based on a conceptual framework for competitiveness in logistics strategy. For support today's logistics managers and scholars, a literature review is established for scrutinize what was previously studied and what needs to be examined. From a focal firm perspective, the research expands the understanding of logistics strategy as a competitive tool while linking customer service effectiveness and the limitations for eventual research.

Design/Methodology/Approach: This study utilizes a systematic literature review to design a suggested conceptual framework for a research agenda on a competitive tool for firm performance on the subject of logistics strategy; the moderating effect of effectiveness of customer service.

Findings: The research paper provides insights into deficiencies in the current logistics strategy literature. The research paper explicitly recommends exploring the logistics strategy as it relates to expected and actual performance moderated by the effectiveness of customer service.

Research limitations/implications: This article makes several unique literature contributions. First it offers the first comprehensive concise overview of the core concepts used for the logistics strategy in the current research. Next, three particular strategies that influence firm performance are examined. Third it explores the customer service effectiveness' moderating effect. Fourth as a competitive tool

Corresponding author: Conrad Ochego Mogaka

E-mail: mogakaconrad@gmail.com

This open access article is distributed under a Creative Commons Attribution (CC-BY) 4.0 license. 
unnoticed problems are then exposed as ideas for potential research in logistics strategy. Eventually, when carrying out a similar exercise, the approach used to perform the systematic literature review can be used as a model for potential researchers.

Practical implications: Contemporary research is aimed at providing a research group that address the needs of modern corporate executives.

Originality/value: As a competitive tool for firm performance, the article presents a suggested conceptual framework for logistics strategy; the moderating effect of customer service effectiveness.

Keywords: competitive tool, customer service effectiveness, firm performance, logistics strategy, systematic literature review, sustainable development.

\section{Introduction}

Through developments in communication and transportation technologies, the value of logistics has expanded exponentially. Logistics has a vital role to play in achieving the basic goal of regional economic integration and growth (Tongzon, 2011). Logistics does have a wider impact than transaction costs and fulfillment on time (Kumar, Andersson \& Rehme, 2010). Therefore, when process strategies, market strategies, as well as information or channel strategies are integrated with the general logistics strategy with a strong focus on customer service, logistics also leads to the competitive responsiveness of the company.

The need for such a high level of customer service therefore drives management to create a wellconsidered and synchronized logistics strategy which maximizes efficiency, customer emphasis and dissemination of information across the network (Kohn, McGinnis \& Kara, 2011). Improving distribution timeliness in logistics networks inevitably results in increased customer satisfaction. Therefore, manufacturing companies which aim to be customer service leaders must maintain those types of competence irrespective of the sector in which they compete. And reliable logistics systems are crucial to maintaining high customer service levels.

Novaes (2007) argues that by retaining an appropriate and pre-established logistics service level, modern logistics strives to completely integrate CS. Daugherty et al. (1998), suggest that high levels of customer service are correlated with logistical capabilities. Esper et al. (2007) agree that while the pursuit for competitive advantage will take place by distinguishing the logistics services offered, that would have an impact on customer service.

Nonetheless, knowing a few of the challenges and limitations of customer service focus is essential. Bowersox et al. (2014) disclose three constraints: the characterization of satisfaction; the fact that happy customers will not be automatically loyal regular customers; and also the solution that this is what satisfies one customer might not completely satisfy another. Christopher (1999) recommends, in this context, defining customer service requirements by market research and understand the complexities of products and services that distinguish customers.

An effective logistics strategy has become highly critical to sustaining a competitive advantage and entering new markets with developments which are emerging, including rising global trade, growing consumer demand for fast tailored response, and removing trade barriers. Halley and Guilhon (1997) used both qualitative and primary evidence to evaluate small business logistics strategies. The findings showed that there were no rational or irrational logistics strategies among small enterprises. Two determining factors linked with the design of a strategy for small business logistics, even so, have been identified. Murphy, Daley, and Dalenberg (1995) found various forms of distribution networks among all the companies surveyed in yet another study of chosen logistics activities of small firms involved in world trade. 


\section{Logistics strategy}

The logistics strategy relates to the process of fulfilling the requirements of customers and is defined by a series of decisions on the key logistics domains of operation of the company in order to attain sustained profitability. Thus, a logistics strategy relies on its context and deals with it by being unique to the situation. Several studies were conducted within the logistics sector to identify contextual factors. McGinnis and Kohn (1993), recognized extent of environmental institutional hostility as well as logistics problem (described as cost percentage of components and materials, decentralized company culture with individual business divisions, besides the large network of vendors/distributors) as contextual factors. Closs, Goldsby and Clinton (1997) introduced the model of emergency logistics where environmental dynamism, environmental aggression, I.T. logistics.

The principle of a generic logistics strategy should be interpreted as a common decision pattern for a range of logistics-related activities. In order to effectively and efficiently satisfy the logistics system requirements of consumers, one or a blend of generic logistics strategies should be introduced and adopted (Fabbe-Costes, \& Colin, 2007).

\section{Methodology}

In a particular context, qualitative approaches typically look for in-depth phenomenon explanations (Naslund, 2002). Those concepts can then be interpreted in order to further grasp or describe the interesting phenomenon (Sachan \& Datta, 2005). The quintessential goal being to find relationships or paradigms that can be structured into more of an explanatory or theoretical scheme from the data (Strauss and Corbin, 1998). Creswell (2016) discusses five techniques to qualitative research: narrative studies, phenomenological analysis, grounded theoretical research, ethnographic research, and case studies. Usually, narrative studies are described for a specific topic area as a lived or told story of a person or entity (Clandinin, 1989).

Although certainly a strong research method the findings of qualitative studies are often criticized as far as how robust they are conducted and perhaps even the interpretative findings provided (Morse, 2015). Explanations are based not just on history, but also on researchers (Creswell, 2016). Qualitative approaches are most likely to be overlooked since interpretations are distinct from the interpretations of other researchers, or because interpretations provided are considered to be incorrect. The qualitative analysis methods need to be addressed in order to allow other researchers to consider the perception foundations of any data set (Schwandt, Denzin \& Lincoln, 1994).

When research is carried out to give us a better view of how the world functions, then it may be important to use a systematic approach to examine past research work critically (Strauss \& Corbin, 1998). The advantages of looking at historical literature facilitate the creation of grounded theory or developed hypothesis from its real or expected applications to the degree that we can presume the value of past research (Morse, 2015). This is the true worth of looking at previous research systematically and comprehensively (Charmaz, 2001).

\section{Systematic Literature Review}

The first known theory of business logistics strategy was developed by Bowersox and Daugherty (1987). Three discrete operational orientations were established, with associated operational trends as well as strategic twirls used to achieve strategic competitive advantage through logistics. Marketbased, process-based, and information-based strategic logistics are included in their original typology. Bowersox and Daugherty (1987) established three dimensional strategic logistics orientation that can be used independently or in collaboration to fulfill the requirements of organizational activity. These are strategy for the process, market, and information or strategy for the channel. It is regarded to be the first recognized category of company logistics strategy (Kohn, McGinns \& Kara, 2011).

When the process, market or even information demands are integrated within the general logistics strategy and customer service is clearly focused, as viewed by one the customer, therefore logistics would contribute significantly to competitive organizational responsiveness (Kohn, McGinns \& Kara, 2011). Existing research takes the view that the typology of Bowersox and Daugherty offers a clear theoretical foundation consistent over time in terms of excellent logistic strategy dimensions. To 
order to achieve competitive flexibility, these measurements should be integrated at many layers of the company advantage (Kohn, McGinns \& Kara, 2011). Through this study, the researcher intends to uncover logistics management strategy complexities as well as understand the dynamics of logistics management strategy to sustain and improve responsiveness competitive.

Autry, Zacharia, and Lamb (2008) assessed 254 multi-industry logistics directors. Their work defined two aspects of logistics strategy, an operational (functional) logistics strategy as well as a logistics strategy which is externally focused. The former has been depicted as identical to the process strategy of Bowersox and Daugherty. The latter has been depicted as somewhat related to the channel or information strategy. McGinnis, Kohn and Spillan (2010) compared the evolution of the logistics strategy from 1990 to 2008 by using the dimensions of Bowersox and Daugherty of process, market and information or channel strategies as predictor variables together with three predicated variables. The predicted variables include; customer service effectiveness, competitive responsiveness of the company and logistics coordination effectiveness to recognize and assess if there are any, the improvements which occurred over that time in the logistics strategy.

The literature on logistics management well describes logistics' position in supply chain management and other activities including sales, manufacturing and procurement (Mentzer, Stank \& Esper 2008). Larson, Poist, and Halldorsson (2007) investigated this topic empirically then reached the conclusion that senior executives in the supply chain do not agree as to whether logistics is a component of supply chain management (unionist perspective) or if the two overlap (intersectionist perspective).

Classifying a logistics strategy as well as typology for a logistics strategy includes the definition of a company's position of logistics strategy (Słowiński, 2008). Logistics strategy is certainly a practical approach that is subordinated to global corporate strategy. The studies is currently being undertaken to find patterns and dynamics that influence the logistics structure, and also the strategy of logistics and production systems. What makes this recognition important is the importance of logistics for businesses, both from the perspective of professionals, company workers wherein logistics and manufacturing processes are executed, and researchers for whom preferences relate to such areas (Hadaś, Stachowiak \& Cyplik, 2014).

A company's logistic approach is the way of achieving the targets. According to the rationale established, the following strategies were described at the general level, whether based on cost minimization, or on differentiation of service (Kisperska-Moroń, 2002): Strategy of substitution, corresponding to overall strategies of cost-leadership; and strategies of complementarity, relating to differentiation and focus strategies. Time compression appears to have been a highly competitive source of advantage associated with strategies of supply chain and logistics and problems to put the right product in the right quantity at the right time for the right customer (Tammela, Canen \& Helo, 2013).

Irrespective of if a single logistics situation for your logistics and geographic environment segment is closest to the truth, or if your future incorporates elements from many, each organization will have to change its current logistics strategy to compete with it. Efficiency in logistics is an important determining factor of gross domestic product. Efficiency in logistics is an important determinant of national income. Knowing and decomposing the logistics efficiency components is important for improving the efficiency of logistics systems and prioritizing transport infrastructure investments.

Heskett's studies in the 1970ies emphasized the benefit of incorporating the role of logistics into the general business plan of the organization. A business strategy typically sets the course, reflects on actions, describes the company, and maintains continuity throughout the entity (Mintzberg, 1998). From the viewpoint of logistics strategy, logistics is considered to help the business strategy of the company and thus aims to improve the efficiency of the company (Bourlakis \& Bourlakis, 2001). In addition, operational approaches must be aligned both together and with the corporate strategy of the organization (Fine \& Hax, 1985). Consequently, this is a necessity that businesses find operational strategies so as to prevent emerging independent of each other as well as company and/or corporate strategy (Hill, 1997).

A logistics strategy's overall objective is to ensure consistency in operations, roles and priorities that might otherwise have been inconsistent in an organization as well as understanding and resolving critical factors in the external environment of the business (La Londe \& Masters, 1994). In addition, 
logistics principles are seen as the bedrock of a company to respond logistically to external pressures (La Londe \& Mason 1993). Logistics literature focused on creating the optimum operations within the given logistics system until the late 1970s (McGinnis \& Kohn 1993). Heskett (1977) addressed the relevance of logistics in corporate strategy, and logistics research began to explore the logistics strategy theory in the 1980 s.

Nonetheless, most studies on logistics strategies target specific fields including warehousing on European post-1992 industry (Clinton \& Closs, 1997). Previous quantitative logistics strategy research was conducted mainly to define various typologies of logistics strategy. Kohn et al. (1990) conducted a survey of manufacturing firms of different sizes in the U.S. covering many sectors in specific geographic regions. The following factors have been defined by factor analysis: dedication to an integrated computer system, customer service, organized logistics, unified customer service, and quality of logistics management. It revealed that, depending on business strategy and the level of external environmental hostility, logistics strategies vary significantly between companies.

In a research, McGinnis and Kohn (1993) built their classification of logistics strategy (intense, balanced, and unfocused) on a questionnaire sent to manufacturing company logistics managers in the United States. That typology of the logistics strategy is based on the following parameters; the challenge of the external environment, which is the level of competitiveness and unpredictability and strategic emphasis, which is the competitive response time of the firm or division. Cooper (1993), centered his classification of logistics strategies on the density of product value and the cost of the commodity as a market factor. The product value density is based on the value of an item in relation to its weight and volume and as a result commodities products are usually delivered to local catchments with a low value density, while products with a high value density are distributed from fairly few supply points.

Cooper emphasized the significance of being able to modify goals in the logistics strategy as market conditions or consumer requirements change for instance, changes in a product life cycle. Many researchers use the logistics approach typology of Bowersox and Daugherty (1987) (for example Clinton and Calantone 1997; McGinnis and Kohn 2002). A complementary research, however, focused on factor analysis, showed there were still significant differences among firms using the different typologies of logistics strategy provided by Bowersox and Daugherty. In the scope of functional logistics research, the similarity between the various typologies of logistics strategy also exists (Clinton \& Closs 1997).

\section{Results}

The paragraphs below includes the systematic literature review findings. Various patterns have been established to better understand the results, which gives an indication of context to findings of previous researches. These topics cover logistics strategies, logistics strategies' relationship with firm performance, and customer service effectiveness. Each thematic area is explored below.

Logistics strategy: Logistics strategy is a strategic and competitive method spanning multiple contributing factors to competitive response of the company (Heskett, 1977). Effective logistics strategy would lead to higher efficiency of company's operations in traditional business structures. Customer service remains recognized as more of a domain of greatest concern for several companies among many operational affected areas. In order to enhance process efficiency, such generic logistics strategies are essentially characterized by basic logistics principles. Persson (1995) suggested the most fundamental principles for optimizing process efficiency, while La Londe and Mason (1993) suggested some logistics principles which create a basis for the response of logistics to external influences. Besides advancing theoretical perspectives about logistics strategy, it really is critical for logistical managers to think about the consequences of the logistics strategy categorization discussed. Managers are keen to find effective ways to coordinate the processes and systems that design and implement its business logistics strategies effectively (Slater \& Olson 2001; Walker and Ruekert 1987). While the strategic recommendations proposed by Bowersox and Daugherty (1987) offer considerable insight into decisions made available to companies in the logistics strategy, subsequent research as well as advancements in the logistics sector suggest that such an original categorization may need to be reconsidered. 
Logistics strategy and firm performance: A logistics strategy must be aligned with the other operational approaches as well as be consistent with the overall characteristics of the business strategy of an organization and thus meet the criteria for a strategy. For specific companies operating along the supply chain, a strategy needs to be developed that satisfies both consumer and other supply chain partners ' requirements (Christopher \& Towill, 2002). The actual performance attained in the previous decade, performance accomplished through virtually identical operations throughout the company, performance reached by many other companies, benchmarks, accepted goals set in the logistics strategy, abject standards as well as recognized industry standards are by far the most broadly utilized sources for all these analogies. Logistics strategy policymakers need a basis to compare national performance over time as well as against global peers. Such information includes key drivers of logistics efficiency, cost and quality indicators of logistics operation, along with metrics for measuring the effect of legislative and financial reform in the industry on economic growth and industrialization (ITF, 2015 as cited by Rezaei, Van Roekel \& Tavasszy, 2018).

Customer service effectiveness: A really well-coordinated logistics strategy often increases the quality of customer service (Kohn, McGinnis \& Kara, 2011). The need for such a high level of customer service therefore drives management to create a well-considered and synchronized logistics strategy which maximizes efficiency, customer emphasis and dissemination of information across the network (Kohn, McGinnis \& Kara, 2011). Improving distribution timeliness in logistics networks inevitably results in increased customer satisfaction. Therefore, manufacturing companies which aim to be customer service leaders must maintain those types of competence irrespective of the sector in which they compete. And reliable logistics systems are crucial to maintaining high customer service levels. To ensure that such a customer is happy and content, the firm may need to reinvent the manufacturing process, distribution or sale of the product. Developing value-added products and services is one way to satisfy the requirements of customer service (Bowersox et al., 2014).

\section{Suggested research agenda}

There is a dearth of information on what is in the existence including features for each of the related strategy categories despite multiple studies stretching more than a decade. Such inconsistencies may emerge from the different samples or even methodological approaches used by the previous research; however, (Autry, Zacharia \& Lamb, 2008) noted that it is also likely that the logistics field has progressed since the initial typology was introduced, and some of the variations in findings may arise from the different perspectives of managing logistics which have advanced at the same time as the study flow.

While many other articles have concentrated on the concept of sustainable development within the context of the supply chain (Seuring and Muller, 2008), there is very little work done to understand the role and importance of logistics in the quest for sustainability of an organization. Customer requirements are rising drastically (PWC, 2016 as cited by Carbone, Rouquet \& Roussat, 2018). All individuals and companies anticipate products to be delivered more efficiently, more flexibly and at low or no shipping price in the case of customers. Manufacturing output is increasingly being personalized, though good for consumers, it is a challenging task for the logistics sector. Crunch the numbers and the industry is under intense and rising pressure to deliver better customer service at a far-low cost (PWC, 2016 as cited by Carbone, Rouquet \& Roussat, 2018).

In an 'one size fits all' logistics approach (lower cost yet minimal service) there are risks due to high cost and complexity in over-customization, the reasonable compromise is to identify three or four concrete categories (Gattorna, 2006). Besides advancing theoretical insights on strategy in logistics, it is necessary for logistics managers to consider the consequences of the logistics strategy categorization mentioned here. Managers are interested in finding better ways to coordinate the tasks and procedures that develop and implement their business strategies effectively (Slater \& Olson, 2001).

More studies in this field also should be considered by researchers in examining the moderating effect of customer service effectiveness on the relationship between varieties of logistics strategies as a competitive tool for firm performance. For example, how does customer service effectiveness moderate the relationship between process strategies and firm performance? How does customer service effectiveness moderate the relationship between market strategies and firm performance? 
Additionally, how does customer service effectiveness moderate the relationship between information or channel strategies and firm performance? Finally, logistics strategies research should also be done at the functions of the logistics network. Below is the suggested cause and effect relationship.

Figure 1: Suggested cause and effect relationship

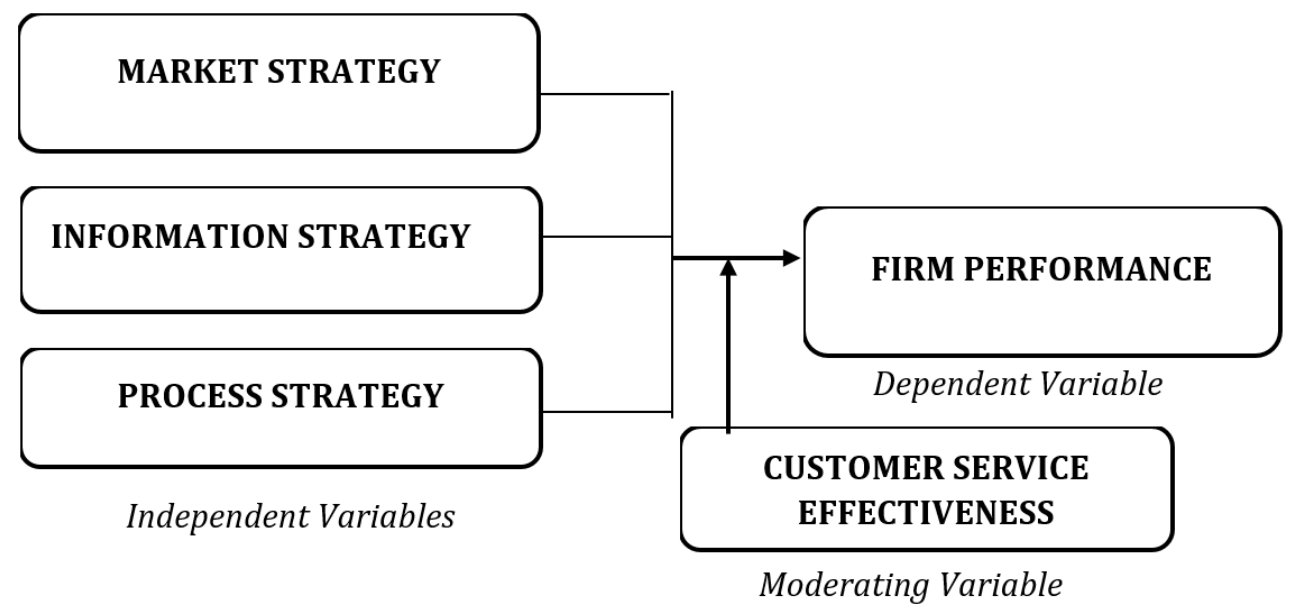

\section{Limitations and conclusion}

There are weaknesses in the existing research. One of the aims of the recent research was to have an objectively designed review of logistics strategy as a strategic resource for firm performance; the moderating impact of effectiveness of customer service that could provide a conceptual framework on how to continue with the study of logistics strategy. This is not a disproof of literature reviews based on tradition or subjectivity. Usually, traditional literature reviews are conducted to facilitate prompt implementation of studies, not so much because authors are wary thorough in-depth analysis. Nonetheless, a systematic literature review on logistics strategy constraints might need to be developed in this case when using an unbiased approach of a literature review on an existing trend in order to keep research advancing. This could have tightly defined the researcher's logistics strategy approach which deterred a selective review of other relevant topics.

In addition, ten academic journals were considered for the systematic literature review, which means that the current literature review did not include some articles from other disciplines and other logistics journals. Third, many papers dealing with different types of logistics strategy due to the emphasis on logistics strategy; in this context the systematic literature review excluded interpersonal relationships from the public sector, service provider only. Future studies should include results from many other relevant fields to see whether this will foster comprehension of logistics strategy as a competitive tool for firm performance. Finally, the purpose of the new studies was to offer a focused company approach of the logistics strategy as the decision to align the logistics strategy with the results of the corporate strategy at the company level.

Nonetheless, a study of logistics strategy from the viewpoint of a logistics network (multiple companies) may be useful in exploring whether there are any gaps between the two viewpoints. This research aims to initiate the further exploration of problems in logistics strategy as a competitive tool for firm performance; the moderating effect of effectiveness of customer service. The systematic literature review acts as the foundation and development of existing logistics strategy research. Despite years of focus on strategy and mixed reviews in logistics management, it seems to be both passive and under-researched. The hope isn't that things could change, but instead a renewed focus on examining issues relevant to the logistics strategy as a competitive tool for firm performance; the moderating effect of effectiveness of customer service will lead to new knowledge to support either researchers, scientists or even practitioners. 


\section{Citation information}

Mogaka, C. O., \& Arani, W. (2020). Logistics strategy as a competitive tool for firm performance: The moderating effect of customer service effectiveness. Journal of Sustainable Development of Transport and Logistics, 5(1), 56-65. doi:10.14254/jsdtl.2020.5-1.6.

\section{References}

Autry, C. W., Zacharia, Z. G., \& Lamb, C. W. (2008). A logistics strategy taxonomy. Journal of Business logistics, 29(2), 27-51.

Barney, J. and Hesterly, W.S. (2013). Administração Estratégica e Vantagem Competitiva, 3rd ed., Pearson Prentice Hall, São Paulo.

Bourlakis, M. A., \& Bourlakis, C. A. (2001). Deliberate and emergent logistics strategies in food retailing: a case study of the Greek multiple food retail sector. Supply Chain Management: An International Journal, 6(4), 189-200.

Bowersox, D. J., \& Daugherty, P. J. (1987). Emerging patterns of logistical organization. Journal of Business Logistics, 8(1), 46.

Bowersox, D. J., Closs, D. J., Cooper, M. B., \& Bowersox, J. C. (2013). Gestão logística da cadeia de suprimentos. AMGH Editora.

Carbone, V., Rouquet, A., \& Roussat, C. (2018). A typology of logistics at work in collaborative consumption. International Journal of Physical Distribution \& Logistics Management, 48(6), 570585.

Charmaz, K., \& Mitchell, R. G. (2001). Grounded theory in ethnography. Handbook of ethnography, 160, 174.

Christopher, M. (1999). A Logistica Do Marketing. Futura, São Paulo.

Christopher, M., \& Towill, D. R. (2002). Developing market specific supply chain strategies. The international journal of logistics management, 13(1), 1-14.

Clandinin, D. J. (1989). Developing rhythm in teaching: The narrative study of a beginning teacher's personal practical knowledge of classrooms. Curriculum Inquiry, 19(2), 121-141.

Clinton, S. R., \& Closs, D. J. (1997). Logistics strategy: does it exist?. Journal of Business logistics, 18(1), 19.

Closs, D. J., Goldsby, T. J., \& Clinton, S. R. (1997). Information technology influences on world class logistics capability. International Journal of Physical Distribution \& Logistics Management, 27(1), 417.

Corbin, J. M., \& Strauss, A. (1990). Grounded theory research: Procedures, canons, and evaluative criteria. Qualitative sociology, 13(1), 3-21.

Creswell, J. W., \& Poth, C. N. (2016). Qualitative inquiry and research design: Choosing among five approaches. Sage publications.

Daugherty, P. J., Stank, T. P., \& Ellinger, A. E. (1998). Leveraging logistics/distribution capabilities: the effect of logistics service on market share. Journal of Business logistics, 19(2), 35.

Fabbe-Costes, N., \& Colin, J. (2007). Formulating logistics. Global logistics: new directions in supply Chain management, (May), 33.

Fernandes, D. W., Moori, R. G., \& Filho, V. A. V. (2018). Logistic service quality as a mediator between logistics capabilities and customer satisfaction. Revista de Gestão, 25(4), 358-372.

Fine, C. H., \& Hax, A. C. (1985). Manufacturing strategy: a methodology and an illustration. Interfaces, 15(6), 28-46.

Gattorna, J. (2006). Living supply chains: how to mobilize the enterprise around delivering what your customers want. Pearson Education.

Hadaś, Ł., Stachowiak, A., \& Cyplik, P. (2014). Production-logistic system in the aspect of strategies for production planning and control and for logistic customer service. LogForum, 10(3).

Halley, A., \& Guilhon, A. (1997). Logistics behaviour of small enterprises: performance, strategy and definition. International Journal of Physical Distribution \& Logistics Management, 27(8), 475-495.

Harrington, L. (1995). Logistics, agent for change--shaping the integrated supply chain. Transportation \& Distribution. 
Heskett, J. L. (1977). Logistics: essential to strategy. Harvard Business Review, 55(6), 85-96.

Hill, T. (1997). Manufacturing strategy-keeping it relevant by addressing the needs of the market. Integrated Manufacturing Systems, 8(5), 257-264.

Kisperska-Moroń, D. (2002). Pozycja konkurencyjna małych i średnich firm $w$ łańcuchach dostaw. Prace Naukowe Akademii Ekonomicznej we Wrocławiu, (944 Logistyka przedsiębiorstw w warunkach przemian), 326-334.

Kohn, J. W., McGinnis, M. A., \& Kara, A. (2011). A structural equation model assessment of logistics strategy. The International Journal of Logistics Management, 22(3), 284-305.

Kumar, N., Andersson, D., \& Rehme, J. (2010). Logistics of low cost country sourcing. International Journal of Logistics: Research and Applications, 13(2), 143-160.

La Londe, B. J., \& Masters, J. M. (1994). Emerging logistics strategies: blueprints for the next century. International journal of physical distribution \& logistics management, 24(7), 35-47.

Larson, P. D., Poist, R. F., \& Halldórsson, Á. (2007). Perspectives on logistics vs. SCM: a survey of SCM professionals. Journal of Business Logistics, 28(1), 1-24.

Londe, B. J. L., \& Mason, R. E. (1993). Some Thoughts on Logistics Policy and Strategies: Management Challenges for the 1980 s. International Journal of Physical Distribution \& Logistics Management, 23(5).

McGinnis, M. A., \& Kohn, J. W. (1993). Logistics strategy, organizational environment, and time competitiveness. Journal of Business Logistics, 14(2), 1.

McGinnis, M. A., Kohn, J. W., \& Spillan, J. E. (2010). A longitudinal study of logistics strategy: 19902008. Journal of Business Logistics, 31(1), 217-235.

Mentzer, J. T., Stank, T. P., \& Esper, T. L. (2008). Supply chain management and its relationship to logistics, marketing, production, and operations management. Journal of business logistics, 29(1), 31-46.

Morse, J. M. (2015). Critical analysis of strategies for determining rigor in qualitative inquiry. Qualitative health research, 25(9), 1212-1222.

Murphy, P. R., Daley, J. M., \& Dalenberg, D. R. (1995). Logistics Practices of Smaller Businesses Currently Engaged in International Trade (Part 2 of 2). Defense Transportation Journal, 10-17.

Näslund, D. (2002). Logistics needs qualitative research-especially action research. International Journal of Physical Distribution \& Logistics Management, 32(5), 321-338.

Novaes, A. G. (2007). Logística e Gerenciamento da Cadeia de Distribuição. 3ª Edição. ed. Rio de Janeiro: Campus Elsevier.

Pagell, M., \& Wu, Z. (2009). Building a more complete theory of sustainable supply chain management using case studies of 10 exemplars. Journal of supply chain management, 45(2), 37-56.

Pearson, J. N., \& Ellram, L. M. (1995). Supplier selection and evaluation in small versus large electronics firms. Journal of Small Business Management, 33(4), 53.

Persson, G. (1995). Logistics process redesign: some useful insights. The International Journal of Logistics Management, 6(1), 13-26.

Rezaei, J., van Roekel, W. S., \& Tavasszy, L. (2018). Measuring the relative importance of the logistics performance index indicators using Best Worst Method. Transport Policy, 68, 158-169.

Ruekert, R. W., \& Walker Jr, O. C. (1987). Marketing's interaction with other functional units: A conceptual framework and empirical evidence. Journal of marketing, 51(1), 1-19.

Sachan, A., \& Datta, S. (2005). Review of supply chain management and logistics research. International Journal of Physical Distribution \& Logistics Management, 35(9), 664-705.

Schwandt, T. A., Denzin, N. K., \& Lincoln, Y. S. (1994). Handbook of qualitative research. Londres, Ed: Denzin \& Lincoln.

Seuring, S., \& Müller, M. (2008). From a literature review to a conceptual framework for sustainable supply chain management. Journal of cleaner production, 16(15), 1699-1710.

Slater, S. F., \& Olson, E. M. (2001). Marketing's contribution to the implementation of business strategy: An empirical analysis. Strategic Management Journal, 22(11), 1055-1067.

Słowiński, B. (2008). Wprowadzenie do logistyki. Wydawnictwo Uczelniane Politechniki Koszalińskiej.

Strauss, A., \& Corbin (1998). Basics of qualitative research: Techniques and procedures for developing grounded theory. 
Tammela, I., Canen, A. G., \& Helo, P. (2013). Time-based competition: Relation to multiculturalism and logistics in international furniture companies. Benchmarking: An International Journal, 20(5), 588606.

Tongzon, J. (2011). Liberalization of logistics services: The case of ASEAN. International Journal of Logistics Research and Applications, 14(1), 11-34.

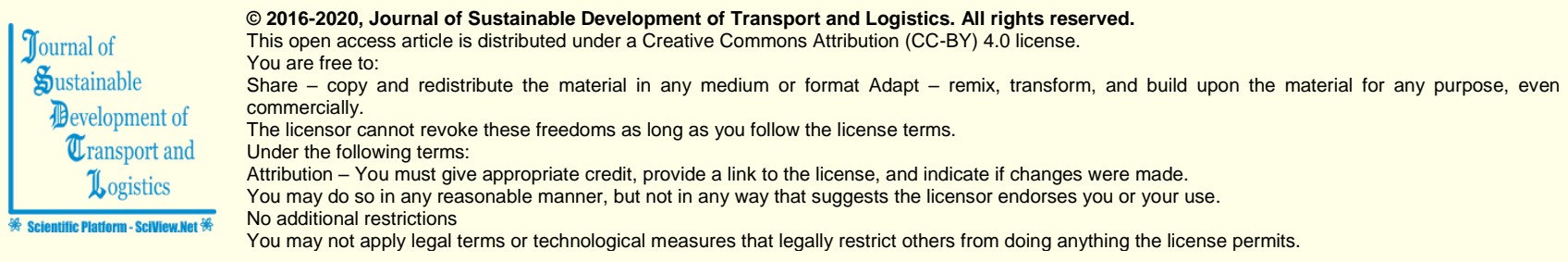

Journal of Sustainable Development of Transport and Logistics (ISSN: 2520-2979) is published by Scientific Publishing House "CSR", Poland, EU and Scientific Publishing House "SciView", Poland, EU

Publishing with JSDTL ensures:

- Immediate, universal access to your article on publication

- High visibility and discoverability via the JSDTL website

- Rapid publication

- Guaranteed legacy preservation of your article

- Discounts and waivers for authors in developing regions

Submit your manuscript to a JSDTL at https://jsdtl.sciview.net/ or submit.jsdtI@sciview.net 